University of Tulsa College of Law

TU Law Digital Commons

Articles, Chapters in Books and Other Contributions to Scholarly Works

2017

\title{
Retributivism and Criminal Procedure
}

Stephen Galoob

Follow this and additional works at: https://digitalcommons.law.utulsa.edu/fac_pub

Part of the Criminal Procedure Commons

\section{Recommended Citation}

Retributivism and Criminal Procedure, 20 New Crim. L. Rev. 465. DOI: 10.1525/nclr.2017.20.3.465

This Article is brought to you for free and open access by TU Law Digital Commons. It has been accepted for inclusion in Articles, Chapters in Books and Other Contributions to Scholarly Works by an authorized administrator of TU Law Digital Commons. For more information, please contact daniel-bell@utulsa.edu. 


\section{RETRIBUTIVISM AND CRIMINAL PROCEDURE \\ Stephen R. Galoob ${ }^{*}$ \\ (forthcoming in NEW CRIMINAL LAW REVIEW)}

Retributivist theories of punishment are in tension with due process. Some retributivists adopt a simple view that punishment of the deserving is normatively justified. However, this Simple Retributivism licenses unjust and illegitimate rules of criminal procedure. A more refined version of retributivism, on which a person's punishment is justified only if she deserves to be punished for the offense with which she is charged and her desert bases cause her to be liable to punishment, avoids the troubling implications of Simple Retributivism. Refined Retributivism also entails specific principles for implementing criminal law - that is, a distinctively Retributivist Criminal Procedure. On this Retributivist Criminal Procedure, procedural mechanisms must establish that there are good reasons to believe that an offender deserves to be punished for an offense, and these reasons must cause the offender's liability to punishment.

Yet Refined Retributivism is also difficult to reconcile with due process. Although Retributivist Criminal Procedure has some salutary implications, it also calls for abolishing core aspects of the U.S. system of criminal justice and features that are essential to any legitimate criminal justice system. Thus, retributivism (whether Simple or Refined) does not provide the basis for a just criminal procedure.

Keywords: retributivism $\bullet$ criminal procedure $\bullet$ punishment $\bullet$ due process

\footnotetext{
* Stephen Galoob is Associate Professor of Law at the University of Tulsa College of Law. He received a J.D. from the University of Virginia and Ph.D. from the University of California, Berkeley. He wishes to thank Craig Agule, David Brink, Vincent Chiao, Russell Christopher, Mihailis Diamantis, Lyn Entzeroth, Chad Flanders, Nathan Hanna, Sam Halabi, Erin Kelly, Josh Kleinfeld, Adam Kolber, Gabriel Mendlow, Alex Sarch, Tommie Shelby, Peter Westen, an anonymous reviewer for this journal, and audiences at the University of Michigan Criminal Law Theory Conference and the University of Oklahoma College of Law Faculty Workshop.
} 


\section{INTRODUCTION}

Retributivism is the view that criminal punishment is justified in large part (and perhaps entirely) by an offender's deserving to be punished. Retributivism is almost certainly the most prominent and influential contemporary theory of punishment. Yet this view is controversial, particularly regarding questions about desert. Retributivists disagree among themselves about the appropriate bases of desert ${ }^{1}$ and what a criminal offender deserves. ${ }^{2}$ Retributivists also disagree with punishment theorists of other stripes about whether criminal offenders can (or routinely do) deserve punishment or harsh treatment. ${ }^{3}$

Can retribution provide what H.L.A. Hart called the "general justifying aim" of a system of punishment, ${ }^{4}$ as many retributivists contend $?^{5}$ Even if the abovementioned controversies about desert could all be resolved, other powerful challenges would remain. How should desert figure into the implementation of retributivism in the criminal justice system? The implementation of retributivism should, at a minimum, be compatible with due process values. If a criminal justice system animated by retributivist principles would be unjust or illegitimate, then retribution cannot be the general aim of the criminal justice system.

\footnotetext{
${ }^{1}$ See R.A. Duff, Choice, Character, and Criminal Liability, 12 LAW \& PHIL. 345 (1993); Jeffrie G. Murphy, The State's Interest in Retribution, 5 J. CONTEMP. LEGAL ISSUES 283 (1994).

${ }^{2}$ See Mitchell Berman, Two Kinds of Retributivism, in PhilosophicAl Foundations of CRIMINAL LAW 433 (R.A. Duff \& Stuart Green eds., 2011); Douglas Husak, What Do Criminals Deserve?, in LEGAL, MORAL, AND Metaphysical Truths: The Philosophy of Michael S. Moore 49 (Kimberly Kessler Ferzan \& Stephen J. Morse eds., 2016).

${ }^{3}$ Compare Michael Louis Corrado, Why Do We Resist Hard Incompatibilism? Thoughts on Freedom and Punishment, in The Future OF PUnishment (Thomas Nadelhoffer ed., 2011); Chad Flanders, Can Retributivism Be Saved?, 2014 BYU L. REV. 309 (2014); Derk Pereboom, Free Will Skepticism and Criminal Punishment, in THE Future OF PUnishment 49 (Thomas Nadelhoffer ed., 2013); John Kleinig, What Does Wrongdoing Deserve?, in Retributivism Has a Past. Has It A Future 46-62 (Michael Tonry ed., 2011); Stephen Morse, Compatibilist Criminal Law, in THE Future of Punishment 107 (Thomas Nadelhoffer ed., 2013).

${ }^{4}$ H.L.A. HART, PUnishment AND Responsibility: EsSAys In The Philosophy OF LAW 9-10 (rev. ed., 2008).

${ }^{5}$ See, e.g., John Finnis, Retribution: Punishment's Formative Aim, 44 AM. J. JURIS. 91 (1999).
} 
Most punishment theorists (including many who write about retributivism) do not extensively analyze questions related to due process or criminal procedure. ${ }^{6}$ A retributivist might explain this neglect by contending that procedural questions are peripheral to the main theoretical ambition of establishing retribution as the general justifying aim of the penal system. ${ }^{7}$ The punishment theorists who have addressed this issue have largely denied that retributivism's procedural implications present any distinctive or perplexing questions. ${ }^{8}$

The neglect of criminal procedure as a theoretical topic is mistaken, and any complacency of retributivists is unwarranted. When the significance of desert is properly understood, retributivism calls for specific principles of implementation. In other words, the best versions of retributivism seem to be committed to a distinctive position, Retributivist Criminal Procedure, according to which an infliction of punishment is just only if criminal justice institutions establish that there are good reasons for the adjudicator to believe that an offender deserves to be punished for a specific offense and these considerations actually cause the offender to be deemed liable to punishment.

\footnotetext{
${ }^{6}$ Several prominent works of punishment theory provide counterexamples to this contention, including JoHN Braithwaite \& Philip Pettit, Not Just Deserts: A Republican Theory of Criminal Justice (1990); Vincent Chiao, Discretion and Domination in Criminal Procedure: Reflections on Pettit, 15 POL. PHIL. \& ECON. 92 (2016); Russell Christopher, Deterring Retributivism: The Injustice of Just Punishment, 96 Nw. U. L. REV. 843 (2002); Donald Dripps, The Substance-Procedure Relationship in Criminal Law, in PHILOSOPHICAL FoundATIONS OF CRIMINAl LAW 409, 410 (R. Anthony Duff \& Stuart Green eds., 2011); ANTONy Duff ET AL., THE TRIAL ON TRIAL: Towards A Normative Theory OF THE Criminal Trial 90 (2007); Paul Roberts, Groundwork for a Jurisprudence of Criminal Procedure, in PHILOsophiCAl Foundations of CRIMINAL LAw 379, 380 (Antony Duff \& Stuart Green eds., 2011); Alec Walen, Proof Beyond a Reasonable Doubt: A Balanced Retributive Account, 76 LA. L. REV. 355 (2015).

${ }^{7}$ For example, Joel Feinberg (following Hart) distinguishes between the "justifying aim of [the] whole system" of criminal law rules and practices and the "rules governing the system's operation," which (for liberal theories) must "at every level ... be fair" but are not otherwise informed by the system's general aim. JOEL FEINBERG, HARMLESS WRONGDOING 148 (1988).

${ }^{8}$ Richard A. Bierschbach \& Alex Stein, Mediating Rules in Criminal Law, 93 VA. L. REV. 1197, 1206 (2007); Michael T. Cahill, Retributive Justice in the Real World, 85 WASH. U. L. REV. 815, 856 (2007).
} 
RETRIBUTIVISM AND CRIMINAL PROCEDURE | 4

This article has three parts. Part I distinguishes two versions of retributivist theories, Simple Retributivism and Refined Retributivism. Simple retributivist theories are objectionable because they misunderstand the significance of desert and license a host of patently illegitimate criminal procedure mechanisms. Retributivists should therefore favor more refined versions of retributivism. Refined Retributivism properly appraises the significance of desert and (based on its implicit theory of criminal procedure) rules out the kinds of illegitimate procedural mechanisms that Simple Retributivism allows.

Part II more fully articulates Retributivist Criminal Procedure and shows how it follows logically from Refined Retributivism. Retributivist Criminal Procedure imposes a causation requirement: in order for someone's punishment to be permissible, the considerations in virtue of which she deserves to be punished must causally influence the infliction of punishment on her. Retributivist Criminal Procedure also imposes a minimal standard of epistemic justification: punishing someone for an offense is permissible only if there is (at least) good reason to believe that she deserves to be punished for that offense. At the systemic level, Retributivist Criminal Procedure holds that criminal procedure institutions may not accept deviations from the causation requirement or the epistemic justification standard in order to realize other procedural values.

Part III analyzes several implications of Retributivist Criminal Procedure. Retributivist Criminal Procedure provides a novel, unified critique of criminal justice practices (such as pretextual stops, pretextual prosecutions, and plea bargaining) that are both common in the United States and widely condemned on other grounds. Yet Retributivist Criminal Procedure is also in tension with several procedural rules and norms that are central to the U.S. system of 
criminal justice and several others that are integral to any just criminal procedure. Thus, Refined Retributivism, like Simple Retributivism, is difficult to reconcile with due process values. ${ }^{9}$

\section{RETRIBUTIVISM, SIMPLE AND REFINED}

Retributivism has many varieties. Every version of retributivism posits an important connection between punishment and desert, although some specify this connection imprecisely. Consider the following formulation.

Simple Retributivism: An infliction of punishment is justified when a person is punished to the extent that is warranted by his desert bases.

Desert bases can be construed broadly to include all of the characteristics, patterns of deliberation, and/or conduct in virtue of which an offender might deserve punishment. ${ }^{10}$ Retributivists disagree about many of the terms in Simple Retributivism - for example, over what counts as punishment and what constitutes a desert basis. Aside from these internecine disputes, a broader criticism of Simple Retributivism is that it leaves out aspects of the effectuation of punishment that are important generally, aspects that should be especially important to retributivists.

Simple Retributivism should be avoided for several reasons. The following case illustrates one such reason.

Proxy: Social scientific evidence establishes that a system in which judgments about criminal charges and criminal liability are made solely by utilizing proxies for deservingness (e.g., past criminal history, race and socio-economic status, residence in a high-crime neighborhood, neck tattoos) results in more accurate determinations than a system that requires legally proving the defendant's desert bases as a precondition to meting out punishment. Based on these findings, the

\footnotetext{
${ }^{9}$ Throughout this article, I use the term "due process" in a generic sense to indicate the procedural values necessary for a just and legitimate system of criminal punishment. My claim about retributivism and due process does not depend on any specific legal or theoretical interpretation of what process is due in the investigation and prosecution of crimes. Thanks to Alec Walen for encouraging me to clarify this point.

10 Joel FeInBerg, DoIng AND Deserving: EsSAys In THE THEORY OF RESPONSIBILITy 58 (1970).
} 
criminal justice system is reformed so that all charging and liability judgments are based on these proxies.

Under this reformed system, Donny is charged with robbing Victoria and found liable for this crime because he possess a sufficient number of the proxy factors (including that he has a criminal history, is classified as African-

American, comes from a bad neighborhood, and has a neck tattoo). As it happens, Donny actually committed the robbery of Victoria for which he is charged and found liable. Therefore, the proxy mechanism produced an accurate punishment in Donny's case.

The mechanism described in Proxy conflicts with basic aspects of due process and guarantees of equal protection under law, for many of the reasons pointed out by critics of so-called "risk prediction" in the criminal justice system. ${ }^{11}$ Yet although this proxy mechanism is problematic, the infliction of punishment in this case does not run afoul of Simple Retributivism. Donny deserves to be punished for robbing Victoria, and he is punished.

What, exactly, is troubling about Proxy? According to one version of retributivism, punishment is more than something that happens in the wake of wrongdoing. Rather, punishment publicly responds to an offender's wrongdoing that condemns the wrongdoer, vindicates the system of law that the wrongdoer violated, and communicates support to the victims (if any) of the wrongdoing. ${ }^{12}$ On these "response" versions of retributivism, Proxy is unsatisfactory because the proxy system uses substitutes for desert bases to mete out punishment. Since the infliction of punishment in Proxy is determined solely by these substitutes, it does not respond to Donny's wrongdoing as such.

\footnotetext{
${ }^{11}$ See Bernard E. Harcourt, Against Prediction: Profiling, Policing, and Punishing in an Actuarial Age (2008); Jonathan Simon, The Ideological Effects of Actuarial Practices, 22 LAW \& Soc. REV. 771 (1988); Sonja B. Starr, Evidence-Based Sentencing and the Scientific Rationalization of Discrimination, 66 STAN. L. REV. 803 (2014).

${ }^{12}$ See R. A. Duff, Political Retributivism and Legal Moralism, 1 VA. J. CRIM. L. 179 (2012); Jean Hampton, Correcting Harms versus Righting Wrongs: The Goal of Retribution, 29 UCLA L. REV. 1659 (1992); Dan Markel, What Might Retributive Justice Be?, in RETRIBUTIVISM: ESSAYS ON THEORY AND POLICY 49-72 (Mark D. White ed., 2011).
} 
Another version of retributivism posits a specific relationship between an offender's desert bases and her punishment, and so would have different objections to Proxy. For example, David Brink defines retributivism as the view that "reactive attitudes and practices of blame and punishment should track desert...."13 The contention that punishment should track an offender's desert bases can be distinguished from the weaker contention that punishment should merely correspond to an offender's desert bases. Tracking implies that the process of meting out punishment must itself be sensitive to an offender's desert bases, that changes in an offender's desert bases must reliably prompt changes in her punishment. ${ }^{14}$ Correspondence does not require this sensitivity. A stopped clock is insensitive to the passage of time, yet its face sometimes corresponds to the correct time. Likewise, in Proxy a procedure that is insensitive to the offender's desert bases nonetheless generates an outcome that corresponds to them. Here, the insensitive procedure winds up producing an answer that is both correct and identical to the one that a sensitive decision procedure would have produced. On the "tracking" version of retributivism, then, the problem in Proxy is that punishment corresponds to, but does not track, Donny's desert bases. If Donny had manifest no desert bases related to Victoria's robbery but had the same proxies (e.g., the same origins, race, criminal history and tattoos), then the procedural mechanisms would have generated the same conclusion about his liability to punishment.

Neither the "response" nor the "tracking" versions of retributivism can be satisfied simply by the realization of a state of affairs in which the deserving have been punished. Rather,

\footnotetext{
${ }^{13}$ David O. Brink, Retributivism and Legal Moralism, 25 RATIO JURIS 496 (2012) (emphasis added).

${ }^{14}$ See David Enoch, Levi Spectre, \& Talia Fisher, Statistical Evidence, Sensitivity, and the Legal Value of Knowledge, 40 PHIL. \& PuB. AfF. 197 (2012); David Enoch \& Talia Fisher, Sense and "Sensitivity": Epistemic and Instrumental Approaches to Statistical Evidence, 67 STAN. L. REV. 557 (2015).
} 
the offender must punished because of her desert bases. ${ }^{15}$ Retributivists, then, seem committed to a causal theory of punishment's justification: for a token of punishment to be normatively justified, someone's desert bases must causally influence ${ }^{16}$ the infliction of punishment. ${ }^{17}$ It is not enough that an offender's punishment is merely proportionate to ${ }^{18}$ or commensurate with $^{19}$ her desert bases. If such proportionality or commensurability were accidental, then the offender would not be punished because she deserves it.

The causal notion helps explain why the Proxy case is problematic for retributivism. Say that a token infliction of punishment is accurate when it corresponds to the offender's desert bases. The retributivist cannot be satisfied by a punishment infliction (as in Proxy) that is accurate but in which the offender's desert bases play no causal role. Even though the verdict in Proxy is accurate, his desert bases do not figure into the explanation of why he is punished. Therefore, the infliction of punishment in this case is normatively unjustified.

More broadly, the retributivist should condemn a criminal procedure mechanism that assigns no role to desert bases in the infliction of punishment. This condemnation applies regardless of the overall accuracy of the results that the mechanism generates. Put differently, the

\footnotetext{
${ }^{15}$ See, e.g., Kent Greenawalt, Punishment, 74 J. CRIM. L. \& CRIMINOLOGY 343, 347 (1983) (“Briefly stated, a retributivist claims that punishment is justified because people deserve it."); Alice Ristroph, Just Violence, 56 ARIZ. L. REV. 1017, 1040 (2014) ("The basic retributive idea is that punishment is justified because the offender deserves it..."); Stephen P. Garvey, Is It Wrong to Commute Death Row? Retribution, Atonement, and Mercy, 82 N.C. L. REV. 1319, 1324 (2004) ("Retributive justice obligates the state to punish an offender because and to the extent, but only to the extent, he deserves to be punished.").

${ }^{16}$ Other retributivists go further, contending that an offender's desert bases must be the sole causal influence on the infliction of punishment. See, e.g., Michael MoOre, Placing Blame: A General TheORY OF THE CRIMINAL LAW 91 (1997) ("Retributivism is a very straightforward theory of punishment: We are justified in punishing because and only because offenders deserve it.”); Christopher, supra note 7, at 859.

${ }^{17}$ Note that the claim here concerns whether punishment is normatively justified. The Refined Retributivist might also embrace the stronger claim that a gesture lacking the requisite etiology is not punishment at all, even if it resembles punishment in all other respects.

${ }^{18}$ See, e.g., Richard W. Burgh, Do the Guilty Deserve Punishment?, 79 J. PHIL. 193, 197-98 (1982).

${ }^{19}$ See, e.g., Dan Markel, Against Mercy, 88 MinN. L. REV. 1421, 1441 (2004); Russ Shafer-Landau, Retributivism and Desert, 81 PAC. PHIL. Q. 189 (2000).
} 
retributivist should be skeptical about a purely instrumental notion of criminal procedure, one in which the goals of the system are set by normative theory and mechanisms of implementation are justified solely in virtue of how well they implement those goals. ${ }^{20}$ Such instrumentalism would neglect the essential causal role for an offender's desert bases in the process of meting out his punishment.

For the retributivist, though, it is not enough that an offender's desert bases merely play some causal role in punishment. Consider a second case, adapted from an example by Christopher Heath Wellman. ${ }^{21}$

Lottery: Authorities conduct a lottery to select who will be punished for highprofile, unsolved crime. Authorities think it is highly likely that Diana was the perpetrator of the crime. Thus, she is given four balls in the lottery, while everyone else is given only one. One of Diana's balls is selected in the lottery, and she is punished for the crime. As it happens, Diana is actually the person who committed the crime.

Like Proxy, Lottery would clearly be inconsistent with due process. The lottery process violates the requirement that the state must introduce evidence of and prove (beyond a reasonable doubt) every element of every offense with which the defendant is charged. The lottery also violates Diana's rights to confront her accusers and challenge the evidence against her. Further, the lottery contravenes Diana's right to assist in her own defense because it eliminates the possibility that she could defend herself at all from the charges against her.

Although some do not recoil in horror from the notion of a punishment lottery, ${ }^{22}$ every retributivist would or should see Lottery as problematic. A system that utilized this kind of

\footnotetext{
${ }^{20}$ Some commentators associate retributivism with an instrumental view about the importance of criminal procedure. See Cahill, supra note 8, and Bierschbach \& Stein, supra note 8. Some provide broader defenses of the instrumental view of procedure. See MARK R. REIFf, PUnishment, COMPENSATION, AND LAW: A THEORY OF ENFORCEABILITY (2005); Jonathan B. Wiener \& Barak D. Richman, Mechanism Choice, in RESEARCH HANDBOOK on Public Choice and Public Law 363 (Anne Joseph O’Connell \& Daniel A Farber eds., 2009).

${ }^{21}$ Christopher Heath Wellman, Procedural Rights, 20 LEGAL THEORY 286, 290 (2014).
} 
weighted penal lottery to establish liability to punishment would "detach[] punishment from desert $^{, 23}$ in a way that is inconsistent with retributivism. The punishment lottery is arbitrary because it leaves too much to luck. ${ }^{24}$ Punishment administered by lottery seems, to paraphrase Justice Stewart's famous dictum, "cruel and unusual in the same way that being struck by lightning is cruel and unusual. ${ }^{, 25}$ Yet Simple Retributivism could not reach the intuitively correct verdict in cases like Lottery, since Diana's punishment corresponds to her desert bases. Further, the penal lottery realizes the kind of causation requirement described above, since Diana's desert bases have some causal influence on her punishment-the increased number of Diana's balls in the lottery increases the chances that she will be punished.

For the retributivist, then, justified punishment requires a tighter connection between desert bases and punishment than is realized in Lottery. ${ }^{26}$ Although Diana's desert bases figure into the decision to punish her, they figure only indirectly. These desert bases should figure more directly if Diana's punishment is to be normatively justified.

The connection between desert bases and punishment might be tightened in two respects. First, an offender's desert bases should make a more significant causal contribution to her

\footnotetext{
${ }^{22}$ For example, Vincent Chiao contends that "under certain conditions, a penal lottery would be fair according to an acceptable second-best standard of fairness." Vincent Chiao, Ex ante Fairness in Criminal Law and Procedure, 15 NEW CRIM. L. REV. 277, 282 (2012). According to Chiao, the penal lottery would be fair (in this second-order sense) but suboptimal, and a system that distributes discretion to legal officials provides a "still better way of distributing punishment" fairly. Id. at 287-90. See also David Lewis, The Punishment that Leaves Something to Chance, 18 PHIL. \& PUB. AfF. 53, 62 (1989) ("[O]ur present practice amounts to a covert penal lottery. If the penal lottery is just, so is our present practice. If not, not.").

${ }^{23}$ Sanford H. Kadish, The Criminal Law and the Luck of the Draw, 84 J. CRIM. LAW \& CRIMINOLOGY 679, 691 (1994).

${ }^{24}$ See, e.g., Stephen J. Morse, Reason, Results, and Criminal Responsibility, 2004 U. ILL. L. REV. 363, 385 (2004); Heidi M. Hurd \& Michael S. Moore, Negligence in the Air, 3 THEOR. INQ. L. 333, 351 (2002).

${ }^{25}$ Furman v. Georgia, 408 U.S. 238, 309 (1972) (Stewart, J. concurring).

${ }^{26}$ Wellman acknowledges this failing in conceding that, even if the use of a punishment lottery were justifiable in an emergency, it would not be justified as a routine mechanism for meting out punishment. Wellman, supra note 21 , at 292 .
} 
punishment than they do in Lottery. Diana's desert bases exert too remote an influence on her punishment because her culpable wrongdoing only marginally increases the prospect that she will be punished, even though officials think it is highly probable that she committed the crime. In cases like this, a retributivist should require an offender's desert bases to generate a greater increase in the chances that she will be punished.

Second, an offender's desert bases should figure robustly, rather than contingently, into the infliction of punishment. Philip Pettit describes robustness in terms of values or goods: someone can enjoy a robustly demanding value "only insofar as [he] enjoy[s] a corresponding, intuitively thinner benefit.... not just actually, but across a certain range of possibilities, where the extent of that range determines the degree of robustness with which [he enjoys] it." ${ }^{27}$ Robust concepts admit of purely counterfactual violations. ${ }^{28}$ For example, Pettit sees friendship as a robustly demanding value. To be someone's friend, you must favor her "reliably or robustly, and not just as a contingent matter: not just as luck or chance or a spasm of good will would have it. ${ }^{29}$ It is possible to determine that someone is not your friend if she would not stand with you in bad times. This conclusion holds even if times never go bad.

Retributivists should favor punishment procedures that attribute robust significance to an offender's desert bases. An offender's actual desert bases should ground her liability to punishment in her actual case. Moreover, if an offender's desert bases were significantly different, then her liability to punishment should (in virtue of these desert bases) differ to a

${ }^{27}$ Philip Pettit, The Robust Demands of the Good: Ethics with Attachment, Virtue, and Respect 2 (2015).

${ }^{28}$ Nicholas Southwood, Democracy as a Modally Demanding Value, 49 Noûs 504 (2015) (the realization of a robustly demanding value "depends not only on what actually happens but also on what would happen in certain non-actual circumstances").

${ }^{29}$ PetTit, supra note 27, at 2. 
similar degree. On this logic, a retributivist should find Lottery problematic because whatever significance this process attributes to Diana's desert bases is too flimsy, and therefore the result is unsafe. ${ }^{30}$ This unsafety is problematic regardless of how Diana's case is resolved. If Diana's desert bases had changed in the time since the crime or Diana had merely been a "usual suspect" who had not committed the crime, then she would not have deserved punishment. However, under the penal lottery, Diana's prospective liability to punishment would not have changed (or changed sufficiently) in these alternative scenarios.

Simple Retributivism should therefore be modified further. For a token of punishment to be normatively justified, an offender's desert bases should play a direct role in (by exerting a significant and robust causal influence on) her punishment. Call this notion the causation requirement. At the case level, the retributivist should condemn punishment inflictions in which the causation requirement is not realized. Systematically, the retributivist should support mechanisms to ensure that the causation requirement is realized.

Yet even these modifications are not enough to meet all the due process challenges facing Simple Retributivism. Consider a third case.

Evil Alibi: Delilah is charged with robbing Valerie five years ago. However, judicial proceedings definitively establish that, at the time of the robbery of Valerie, Delilah was actually robbing and murdering Theresa in another jurisdiction in which the statute of limitations for all crimes is three years. Delilah is nonetheless convicted of and punished for robbing Valerie, on the rationale that exoneration of this crime would let her off the hook for her crimes against Theresa.

In the Evil Alibi case, Delilah's desert bases (that is, her culpable wrongdoing) causally influence her punishment. These desert bases also figure directly and robustly into the

\footnotetext{
${ }^{30}$ On epistemic accounts that adopt the "safety" principle as a requirement for knowledge, S's belief in $\mathrm{p}$ counts as knowledge only if "in most nearby possible worlds in which $\mathrm{S}$ continues to form her belief about [p] in the same way as in the actual world the belief continues to be true." Duncan Pritchard, Anti-Luck Epistemology, 158 SYNTHESE 277, 282-83 (2007).
} 
explanation of why Delilah is punished. Therefore, on a version of Simple Retributivism that incorporates the causation requirement, Delilah's punishment is normatively justifiable, although perhaps less than what she ultimately deserves.

Intuitively, however, punishment in the Evil Alibi case does not seem to be justified or legitimate. It is certainly inconsistent with due process. The explanation is that Delilah is innocent, but in a sense that might seem trivial. Say that someone is trivially innocent of an offense when she did not commit that offense, but committed another offense (or offenses) of at least equal seriousness. In Evil Alibi, Delilah is trivially innocent of robbing Valerie because, although she did not rob Valerie, she committed the more serious offenses of robbing and murdering Theresa.

As a matter of due process, being trivially innocenct of a charged offense is a barrier to being punished for that crime. In the U.S. criminal justice system, punishments are based on specifically charged offenses. Punishment for uncharged offenses is illegitimate, and innocence of a charged offense is sufficient to establish immunity to punishment for that offense. ${ }^{31}$ The offense restriction, then, is the notion that a defendant's desert bases only bear on her liability to punishment if they are related to the offense for which she is charged.

The offense restriction seems so basic that retributivists often take it for granted. ${ }^{32}$ They should not. Simple Retributivism cannot explain why punishment of the trivially innocent is illegitimate. Simple Retributivism suggests that inflicting punishment in the Evil Alibi case is

\footnotetext{
${ }^{31}$ See, e.g., Brandon Garrett, Claiming Innocence, 92 MINN. L. REV. 1629, 1704-10 (2008); Samuel Morrison, The Politics of Grace: On the Moral Justification of Executive Clemency, 9 BUFF. CRIM. L. REV. 1, 22-23 (2005).

${ }^{32}$ To this end, the Refined Retributivist might include something like the offense restriction as part of the definition of punishment. Alec Walen, Retributive Justice, in STANFORD ENCYCLOPEDIA OF PHILOSOPHY (Edward N. Zalta ed., 2015), http://plato.stanford.edu/archives/sum2015/entries/justice-retributive/ (contending that retributivism is commited as a conceptual, rather than substantive, matter to the proposition that "one cannot punish another whom one believes to be innocent"). Thanks to Peter Westen for encouraging me to consider this possibility.
} 
perfectly acceptable. That Delilah has committed an offense is sufficient to establish that she deserves punishment. Indeed, the Simple Retributivist (echoing Kant) might see the proposition that someone has committed a crime as simply equivalent to the proposition that he deserves punishment. ${ }^{33}$ Further, as noted above, the problematic aspect of the Evil Alibi case cannot be explained in terms of the causation requirement, since Delilah's desert bases (i.e., her culpable robbing and killing of Valerie) figure directly and robustly into the imposition of her punishment.

Yet punishment in Evil Alibi is problematic. More generally, the offense restriction seems integral to legitimate punishment under any theory of punishment. A version of retributivism that denied the offense restriction would invite powerful objections. First, such a view would not be able to guard against punishment of those who have not committed the crime with which they are charged, which is routinely taken to be a main advantage of retributivism

${ }^{33}$ See, e.g., David Gray, Punishment as Suffering, 63 VAND. L. REV. 1617, 1664 (2010) (“[P]unishment can only be imposed 'because [the agent] has committed a crime,' that is, because it is deserved.") (citations omitted). 
RETRIBUTIVISM AND CRIMINAL PROCEDURE | 15

over consequentialism. ${ }^{34}$ Second, that trivial innocence bars conviction is a fundamental element of due process, although (arguably) not an independent tenet of U.S. constitutional law. ${ }^{35}$

To rule out conviction of the trivially innocent, a retributivist should permit only desert bases related to the charged offense to cause the offender to be punished. Someone's characteristics or conduct unrelated to the charged offense may not causally influence her liability to punishment, even if these non-offense-related desert bases are (in the abstract) sufficient to justify punishment. The retributivist is therefore committed to the seeing a defendant's desert bases as non-fungible determinants of whether punishment is justifiably imposed on her.

To recap, Proxy is problematic because the defendant's desert bases do not play a causal role in the offender's punishment; Lottery is problematic because the defendant's desert bases figure too contingently into her punishment; and Evil Alibi is problematic because the

\footnotetext{
${ }^{34}$ See, e.g., R. A. DUfF, TRIALS AND PUNISHMENTS 154 (1991) (“A system of [consequentialist] punishment is most obviously defective if it involves the deliberate punishment of the innocent."). A Refined Retributivist might argue that punishing the trivially innocent is acceptable (and thus resist the impetus to refine Simple Retributivism) in a few possible ways. First, the Refined Retributivist might identify commission of the offense as part of the desert basis. This would be tantamount to adopting "legal," rather than "moral," retributivism. However, this invocation of legal retributivism would beg the question that is of interest here-namely, whether there is logical space between the proposition "the defendant got what she deserved" and "the defendant got what she deserved to get for the charged offense."

Alternatively, one might deny that the trivially innocent are innocent in a way that would preclude the normative justification for punishing them. Along these lines, the Refined Retributivist might appeal to a version of "whole-life" view of punishment. See Victor TAdros, The EndS of HARM: THE Moral Foundations of Criminal Law 68-70 (2011); W. A. Parent, The Whole Life View of Criminal Cesert, 86 Ethics 350 (1976); Gertrude Ezorsky, Retributive Justice, 1 CANADIAN J. PHIL. 365 (1972). Such a "whole-life" view would support the argument that what someone has done over her whole life is relevant to whether she should be punished. However, this strategy is not promising because, as Tadros notes, the whole-life view is a reductio to be avoided. See TADROS, THE ENDS OF HARM, at 68-73.

${ }^{35}$ The constitutions of some U.S. states recognize that conviction of the innocent violates due process. See, e.g., People v. Washington, 665 N.E.2d 1330 (Ill. 1996). However, as Brandon Garrett notes, the U.S. Supreme Court "has yet to recognize a freestanding constitutional claim of actual innocence, except by assuming hypothetically that it might violate due process for an innocent person to be executed." Brandon L. Garrett, Accuracy in Sentencing, 87 S. CAL. L. REV. 499 (2014).
} 
inappropriate desert bases cause the defendant's punishment. These cases suggest the following alternative to Simple Retributivism.

Refined Retributivism: An infliction of punishment is normatively justified if, and only if, (a) a person is punished because of and to the extent that is warranted by his offense-related desert bases, and (b) these offense-related desert bases figure significantly and robustly into the determination that he is liable to punishment.

In essence, Refined Retributivism adds the causation requirement and the offense restriction to Simple Retributivism. A retributivist who finds the Proxy, Lottery, and Evil Alibi cases to be problematic should accept Refined Retributivism and reject Simple Retributivism.

Without fully defending Refined Retributivism here, two contentions can be made on its behalf. First, Refined Retributivism is consistent with due process in a way that Simple Retributivism is not. The examples above indicate that Simple Retributivism is highly revisionist. In denying the offense restriction, it does not require that punishment be meted out based on charged offenses. Nor does it capture numerous due process considerations that are essential to justified punishment, such as rules requiring the prosecution to prove every element of a charged offense or precluding the infliction of criminal punishment based solely on the defendant's bad character or prior bad actions. Yet each of these considerations is integral to the legitimacy of a criminal justice system, and each is also consistent with Refined Retributivism. Limiting punishment to charged offenses (rather than allowing it to be based on prior acts or bad character) furthers the offense restriction by ensuring that only offense-related desert bases provide the basis for punishment. Similarly, many evidentiary rules (for example, those requiring the exclusion of character evidence or evidence of prior criminal behavior) operate to ensure that an offender is not deemed liable to punishment because of desert bases unrelated to the charged offense. 
A second contention on behalf of Refined Retributivism is that it is compatible with (indeed, implicit in) existing retributivist theories. To demonstrate this point, consider the retributivist theories advanced by Michael Moore and Mitchell Berman. ${ }^{36}$ Both of these highly sophisticated theories can be read to embrace either Simple or Refined Retributivism. However, Refined Retributivism ultimately provides best interpretation of each view.

According to Moore, the function of criminal law is to attain "retributive justice," which demands "that those who deserve punishment get it." ${ }^{37}$ In places, Moore offers a teleological interpretation of retributive justice. "To serve retributive justice," he contends, "criminal law must punish all and only those who are morally culpable in the doing of some morally wrongful action. ${ }^{38}$ Moore's formulation here presupposes an instrumentalist approach to criminal procedure: criminal procedure should effectuate the punishment of all and only the deserving. For Moore, retributivism entails an obligation to "set up institutions so that retribution is achieved." ${ }^{, 39}$ Moore's use of the passive voice indicates that what matters is attaining retribution, rather than the specific way that retribution is attained. This formulation of Moore's theory therefore invokes Simple Retributivism: justice is achieved whenever (and criminal procedure should ensure that) all and only those who have acted in a morally wrongful way are punished. This interpretation of Moore's view would omit both the causation requirement and the offense restriction.

Elsewhere, however, Moore interprets retributive justice in a way that more closely resembles Refined Retributivism. "To achieve retributive justice," Moore argues, "the

\footnotetext{
${ }^{36}$ The focus on Moore's and Berman's theories is exemplary. A host of other varieties of retributivism can also be formulated in terms of Refined Retributivism.

${ }^{37}$ MOORE, supra note 16 , at 33.

${ }^{38} I d$. at 35 .

${ }^{39} I d$. at 91 (emphasis added).
} 
punishment must be inflicted because the offender did the offence. To the extent that someone is punished for reasons other than that he deserves to be punished, retributive justice is not achieved. ${ }^{40}$ This formulation suggests both the causation requirement (that an offender's desert bases should figure directly into story of the infliction of punishment on him) and the offense restriction (the only desert bases that should play this causal role are those related to the offense). By implication, a token of punishment violates retributive justice if the offender's desert bases do not figure in the infliction or if extraneous considerations do.

Thus, Moore seems to offer two slogans for retributive justice: "Punish all and only those people who deserve to be punished" and "Punish a person for a crime because (and only if) he deserves to be punished for that crime." These two slogans are not equivalent. Each leads to different verdicts about the legitimacy of punishment in particular cases, and each presupposes a different view about the point of criminal procedure. "Punish all and only those people who deserve to be punished" can countenance the punishment of a morally culpable offender based on considerations other than her desert bases (as in Proxy) or for offenses other than those with which she has been charged (as in Evil Alibi). Given Moore's interpretation of retributivism in causal terms, the slogan "Punish a person for a crime because (and only if) he deserves to be punished for that crime" seems to be the more considered formulation of Moore's view. This slogan is consistent with Refined Retributivism and inconsistent with Simple Retributivism.

Mitchell Berman's "integrated dualist" theory of punishment also might be taken to embrace both Simple and Refined Retributivism. Berman distinguishes "core" cases (which involve "imposition of [punishment] on an actual offender on account of his offense, and only so long as the imposition satisfies some reasonable proportionality constraint, whether of a

\footnotetext{
${ }^{40} I d$. at 28.
} 
retributivist or Benthamite variety") ${ }^{41}$ from "peripheral" cases (which "involve imposition of punishment on persons who are not wrongdoers, either because no offense occurred or because, although it did, the individual was not responsible for it"). ${ }^{42}$ Berman argues that retributivism offers the best justification for punishment in core cases, although some form of consequentialism justifies punishment in peripheral cases. ${ }^{43}$

However, it is difficult to pin down whether Berman's account of the retributivist justification for punishment in core cases is an example of Simple or Refined Retributivism. At one point, Berman contends that "core cases of punishment are justified because the offender's desert renders the fact that punishment inflicts suffering wholly inert as a reason against it - that is, the offender's suffering is not a bad and no right of his is infringed." ${ }^{\text {"44 }}$ Berman also describes his position as "that wrongdoers deserve to suffer on account of their blameworthy wrongdoing. ${ }^{\not 4}$ These statements seem to embrace the causation requirement, but not the offense restriction. In both of these statements, the transformative agent is the offender's wrongdoing as such, rather than his offense-related desert bases in particular.

Elsewhere, Berman embraces the offense restriction, but only in part.

[C]ore cases of punishment are justified, against the suffering they inflict, by cancellation. When the person punished is morally responsible for the commission of an offense, then her suffering on account of that offense, and commensurate with her blameworthiness, simply is not a bad. Furthermore, the state's inflicting what it takes to be deserved suffering, for the sake of realizing

\footnotetext{
${ }^{41}$ Mitchell Berman, Punishment and Justification, 118 ETHICs 258, 261 (2008).

${ }^{42} I d$. at 261.

${ }^{43}$ Id.

${ }^{44} I d$.

${ }^{45} I d$. at 269.
} 
such desert, does not infringe the offender's rights insofar as such infliction treats the offender with respect as a person. ${ }^{46}$

By way of background, Berman contends that justifying punishment requires justifying both that the offender suffers and that the state inflicts this suffering. In requiring suffering to be "on account of" a criminal offense, Berman concedes that only offense-related desert bases can change the moral status of suffering imposed as punishment for an offense. However, Berman also contends that the infliction of punishment does not violate the offender's rights if this infliction serves to "realiz[e the offender's] desert." Yet, in cases of trivial innocence (such as Evil Alibi), an offender's desert is realized by inflictions caused by her non-offense-related desert bases. If realization of desert bases is all that matters, then Berman's account does not impose the offense restriction as a requirement for justified punishment (although the offense restriction is required for justified impositions of suffering).

The best reading of Berman's view seems to be that both the causation requirement ${ }^{47}$ and the offense restriction ${ }^{48}$ apply to each aspect of the retributivist justification for punishment. If so, then Berman's view might be reformulated in light of Refined Retributivism as follows: in core cases, the offender's suffering is justified if, and only if, the offender's offense-related desert bases causally influence the process by which the offender suffers or is punished; and the

\footnotetext{
${ }^{46} I d$. at 284 (emphasis added).

${ }^{47}$ The causation requirement might be implicit in Berman's view. Recall that, on Berman's definition, core cases of punishment involve punishment (and suffering) "on account of" an offense. Much hangs on whether the "on account of" is understood in a normative sense (that an offender's offense must provide a fundamental justification for her punishment), causally (that punishment must be prompted by an offender's offending), or in some other way. One plausible interpretation of "on account of" is that the offense must both ground and prompt the imposition of punishment. If so, then the causation requirement would apply globally to Berman's argument.

${ }^{48}$ The offense restriction, too, might be read out of Berman's broader claim that punishment be "on account of" an offense. On one natural reading of this phrase, any version of retributivism necessarily rules out impositions prompted by non-offense-related desert bases because tokens caused by those desert bases would not be "on account of" an offense. The general applicability of the offense restriction is also suggested by Berman's concession that "pre-offense suffering is strictly irrelevant to the offender's liability to punishment." Id., at 269. To be sure, Berman does not discuss the (ir)relevance of pre-offense desert bases. However, it would be strange to posit that pre-offense suffering is irrelevant to the justification of punishment, while allowing that pre-offense desert bases could matter.
} 
state's infliction of that punishment is justified if, and only if, the offender's offense-related desert bases cause the infliction of punishment.

Retributivists, then, should embrace Refined Retributivism over Simple Retributivism. Simple Retributivism licenses egregious due process violations that Refined Retributivism does not. Refined Retributivism is also implicit in many extant versions of retributivism and provides the best interpretations of two of the most sophisticated theories of retributivism.

\section{REFINED RETRIBUTIVISM AND RETRIBUTIVIST CRIMINAL PROCEDURE}

Unlike Simple Retributivism, Refined Retributivism sees criminal procedure as integral to the justification of punishment. If Refined Retributivism is the superior view, then it follows that at least some questions about criminal procedure matter centrally to the normative justification of punishment—that "just punishment" presupposes a "just process." 49 Defending Refined Retributivism therefore requires articulating a Retributivist Criminal Procedure.

One core aspect of Retributivist Criminal Procedure is that a punishment is normatively justified only if the determination that the offender is liable to punishment is epistemically justified. Call this the justification standard. Justification is one of the central topics of epistemology. Consider a broad, relatively uncontroversial notion of epistemic justification: that [someone's] belief in X is justified entails that there are [or that she has] good reasons (under the applicable standard of proof) to believe $\mathrm{X} .{ }^{50}$ For some commentators, ${ }^{51}$ justification as the

${ }^{49}$ Roy Sorensen, Future Law: Prepunishment and the Causal Theory of Verdicts, 40 Noûs 166, 182 (2006).

${ }^{50}$ This definition is meant to be capacious enough to be consistent with internalism, externalism, reliabilism, coherentism, contextualism, virtue theory, and naturalism regarding justification.

${ }^{51}$ See, e.g., H. L. Ho, A Philosophy of Evidence Law: Justice in the SeArch for Truth 93 (2008); Jordi Ferrer Beltrán, Legal Proof and Fact Finders' Beliefs, 12 Legal Theory 293, 294 (2006); Sorensen, supra note 49, at 170 . 
general standard of legal proof - that is, a verdict is just only if the adjudicator has "not merely good reason, but reason of a kind which would make it not be just luck... if the verdict is true., ${ }^{, 52}$

On Refined Retributivism, the offense restriction states the epistemic goal for which the adjudicator's performance matters. To find that a defendant is liable to be punished for an offense, the adjudicator must have a good reason to believe (or, on some accounts of justification, must believe for a good reason) that she has manifested offense-related desert bases. If any standard less demanding than justification applied, then the defendant's punishment would not be caused by her offense-related desert bases in the way that Refined Retributivism calls for.

To be sure, Refined Retributivism might impose a more demanding epistemic standard than justification. For example, the Refined Retributivist might adopt a "justified true belief" standard, requiring that the adjudicator have a justified true belief that the offender manifested offense-related desert bases. ${ }^{53}$ Under such a "justified true belief" standard, but not under the justification standard, "a verdict based on justified beliefs will still have failed its [epistemic] aim if it turns out to be false." ${ }^{, 54}$ An even more demanding "knowledge" standard would require that the adjudicator know (rather than merely having a justified true belief) that the offender manifested offense-related desert bases. ${ }^{55}$ The justified true belief standard fails to rule out the possibility that the protagonists in Gettier cases have knowledge. However, the usual intuition is that these protagonists do not have knowledge. More broadly, Michael Pardo argues, the same

\footnotetext{
52 Judith Jarvis Thomson, Rights, Restitution, AND Risk: Essays in Moral THEORY 244-45 (1986).

${ }^{53}$ See Michael Pardo, The Gettier Problem and Legal Proof, 16 Legal Theory 37, 41 (2010) (citation omitted).

${ }^{54} I d$. at 41.

${ }^{55}$ Id. at 42, 51-52. See also DUFF ET AL., supra note 6, at 90 ("“ [K]knowledge rather than truth [is] the proper aim of the trial.").
} 
considerations that make justified true beliefs insufficient for knowledge in Gettier cases also make it the case that legal verdicts based solely on justified true beliefs fail to achieve their epistemic goal. ${ }^{56}$ On Pardo's view, legal verdicts "require more than truth and justification.... truth and justification also need to be connected in an appropriate way" in order "to achieve their goal or aim. ${ }^{, 57}$ Although there might be benefits to these more demanding epistemic standards, there might also potential drawbacks. For the purposes of assessing Retributivist Criminal Procedure, however, it does not matter which epistemic standard the Refined Retributivist adopts, so long as the standard is at least as demanding as the justification standard. ${ }^{58}$

Commentators such as H. L. Ho, Jordi Ferrer Beltrán, and Pardo defend justification as a general legal standard. On their position, any normatively justified verdict must meet a standard at least as demanding as epistemic justification. ${ }^{59}$ For our purposes, it is unnecessary to provide such a general defense of the justification standard. Rather, the point is that Refined Retributivism is committed to the justification standard in the context of punishment-in particular, for the adjudication that the offender has manifested desert bases related to the offense with which he is charged.

Another core aspect of Retributivist Criminal Procedure is the causation requirement described above in Part I. For a punishment infliction to be normatively justified, the defendant's

\footnotetext{
${ }^{56}$ Pardo, supra note 53, at 50. As noted below, the Refined Retributivist's substantive commitment to the causation requirement might provide an independent route to avoid the Gettier-style counterexamples that arise under weaker epistemic standards than knowledge and (according to Pardo) allow legal verdicts to fall short of their epistemic goal.

${ }^{57}$ Id. at 52 .

${ }^{58}$ Moreover, each of the implications of Retributivist Criminal Procedure described in Part III is cognizable regardless of whether the applicable epistemic standard is justification, justified true belief, or knowledge.

${ }^{59}$ To be sure, this contention is disputed. Alex Stein, for example, acknowledges that adjudicative fact-finding involves "relaxed" criteria that "do not even purport to satisfy the 'justified true belief' standard or similar criteria for knowledge.” Alex Stein, Foundations of Evidence LaW 59 (2005).
} 
offense-related desert bases must exert a direct and robust influence on the determination that she is liable to punishment. Otherwise, she is not punished because she deserves it. This causation requirement is a substantive commitment of Refined Retributivism. ${ }^{60}$

Another way to state the Refined Retributivist position is that a verdict must satisfy both the causation requirement and the justification standard in order to have what Larry Laudan calls "validity." ${ }^{\prime 61}$ Retributivist Criminal Procedure's commitment to avoiding invalid verdicts derives from of Refined Retributivism. If either the justification standard or the causation requirement were violated in a particular case, then the offender would not be punished because of her offense-related desert bases. ${ }^{62}$ This commitment prevents retributivism from sliding into Simple Retributivism, which might countenance verdicts that are accurate but invalid. The central principle of Retributivist Criminal Procedure, then, is that criminal procedure should avoid invalid verdicts.

The commitment to avoiding invalid verdicts provides Refined Retributivism with resources to evaluate both specific inflictions of punishment and the criminal justice system as a whole. ${ }^{63}$ Under Retributivist Criminal Procedure, a token infliction of punishment is normatively unjustified if it is invalid. An infliction that lacks epistemic justification-for example, where

\footnotetext{
${ }^{60}$ The causation requirement might also be implicit in the epistemic standard implicit in a Refined Retributivist view-for example, if one adopts the view that knowledge, rather than justification, is the standard for all normatively justified legal verdicts.

${ }^{61}$ Larry LaUdAn, Truth, ERror, and Criminal LaW: AN ESSAy in Legal Epistemology 13 (2006).

${ }^{62}$ The justification standard and the causation requirement do not necessarily exhaust Retributivist Criminal Procedure. For example, the Refined Retributivist might (after Pardo) require a more demanding epistemic standard than justification. However, these two notions seem like a baseline for Retributivist Criminal Procedure. No Refined Retributivist could settle for an epistemic standard less exacting than justification. Nor could a Refined Retributivist countenance punishment based on accidents or deviant causal chains. Therefore, these two notions are treated as equivalent to Retributivist Criminal Procedure for the remainder of the article.

${ }^{63}$ Simple Retributivism might also be formulated as applying at the level of systems and the level of cases. Moreover, it is possible that a case-focused version of Simple Retributivism could avoid some of the due process infirmities highlighted in Part I. Thanks to Craig Agule and Mihailis Diamantis for identifying this discrepancy.
} 
there is no good reason for the adjudicator to believe that the offender manifested offense-related desert bases as alleged — would thus be normatively unjustified. So, too, would an infliction in which the adjudicator has justified beliefs about the offender's desert bases, but these beliefs do not causally influence the offender's liability to punishment.

At the systemic level, Retributivist Criminal Procedure calls for adjudication mechanisms that appropriately track the desert bases of offenders. The systemic logic of Retributivist Criminal Procedure requires eliminating invalid verdicts. ${ }^{64}$ Since Refined Retributivism cannot countenance an invalid verdict when assessing a specific case, consistency requires a similar intolerance to invalid verdicts when assessing criminal justice institutions as a whole. In other words, the Refined Retributivist cannot simultaneously treat desert as categorically important at the token level but only contingently important (that is, capable of being overridden by other values or benefits) at the system level.

Retributivist Criminal Procedure’s commitment to avoiding invalid verdicts has a number of practical implications, some of which are explored in more depth in Part III. At a minimum, Refined Retributivism favors standards of proof and rules of evidence to ensure that verdicts implicate the offender's offense-related desert bases in the requisite way. Refined Retributivism also demands that each defendant have opportunities to avoid punishment inflictions that lack epistemic justification - for example, by having the opportunity to challenge a sentence on the grounds that one's offense-related desert bases did not appropriately figure into the determination of one's liability.

\footnotetext{
${ }^{64}$ Saying that Retributivist Criminal Procedure cannot countenance any invalid verdicts does not imply that minimizing such verdicts is its only possible goal. To be sure, the minimization of inaccurate and invalid verdicts is certainly an overriding goal of certain (deontic) retributivist theories, which emphasize the claim that retributivism precludes punishment of the innocent. However, the same is not true of other versions of retributivism, such as those that prioritize realization of the intrinsic good of punishing the deserving. See, e.g., Cahill, supra note 8, at 833-34.
} 
At the systemic level, Retributivist Criminal Procedure's commitment to avoiding invalid verdicts contrasts with the view that promoting accuracy is the main goal of criminal procedure. One position along these lines is that criminal procedure should be assessed based on "case accuracy," or whether "the result in a particular case was correct." 65 Another position is that the goal of criminal procedure is "systemic accuracy," or the maximization of "accurate results in all future cases." ${ }^{, 66}$ Many theorists see systemic accuracy as the goal of criminal procedure, ${ }^{67}$ and of procedural rules more broadly. ${ }^{68}$ Systemic accuracy is often posited to be the overriding procedural goal for consequentialist theories of punishment generally, and deterrence theories in particular. ${ }^{69}$

Some contend that retributivism enshrines accuracy (either at the case level or at the systemic level) as the overriding goal of criminal procedure. For example, Richard Bierschbach and Alex Stein suggest that retributivists should evaluate procedural mechanisms in terms of case accuracy, favoring mechanisms "to the extent that they can achieve ultimate factual

${ }^{65}$ Larry B. Solum, Procedural Justice, 78 S. CAL. L. REV. 181, 247 (2004).

${ }^{66} I d$.

${ }^{67}$ See, e.g., Erik Lillquist, Improving Accuracy in Criminals Cases, 41 U. RICH. L. REV. 897, 931 (2006); Enoch et al., supra note 14 , at 212 .

${ }^{68}$ Louis Kaplow, The Value of Accuracy in Adjudication: An Economic Analysis, 23 J. LEGAL STUD. 307,308 (1994).

${ }^{69}$ To borrow Bentham's distinction, the deterrence theorist sees criminal adjudication as an "adjective branch of law," in that it modifies the "substantive" branch of the law. JEREMY BENTHAM, Principles of Judicial Procedure with the Outlines of a Procedure Code, in 2 THE WORKS OF JEREMY BENTHAM 6 (John Bowring ed., 1843). On Bentham's version of deterrence, the primary goal of adjectival law is to "insure that the will of the legislator is carried out," and "the best way to do this is to insure that the law is accurately applied." Gerald J. Postema, The Principle of Utility and the Law of Procedure: Bentham's Theory of Adjudication, 11 GA. L. REV. 1393,1416 (1977). Since, for the deterrence theorist, the primary point of criminal law is to deter wrongdoing, the procedural goal of systemic accuracy is important to the extent that inaccuracy blunts the criminal law's deterrent effect. See, e.g., id., at 1421; see also Kaplow, supra note 68, at 310; Dripps, supra note 6, at 415. 
accuracy of outcomes in individual cases. ${ }^{, 70}$ Along these lines, Michael Cahill sees systemic accuracy as the lodestar of retributivism's criminal procedure. On Cahill's consequentialistflavored version of retributivism, the goal of the criminal justice system is to "maximize the total amount of deserved punishment the system imposes," with the total being a function of "the number of offenders caught, the amount of (deserved) punishment per offender, and the cost of apprehending each offender." ${ }^{, 71}$ Cahill contemplates that the retributivist might even favor rules of criminal procedure that "generate results that run counter to desert in some cases," so long as these rules have the effect of "making retributively 'right' outcomes more likely" in the "majority of cases." " If (as both Bierschbach and Stein and Cahill contend) the main point of criminal procedure is to achieve accurate (rather than valid) results, then retributivism supports any procedural mechanism that ensures or improves the accuracy of verdicts.

Yet prioritizing accuracy over validity in this way presumes Simple Retributivism and conflicts with Refined Retributivism. Refined Retributivism could not countenance a verdict that is accurate but invalid - for instance, a verdict (like the ones in Proxy and Lottery) that is only accidentally correct. Such a verdict would violate the causation requirement. Nor could Refined Retributivism countenance a verdict (like the one in Evil Alibi) in which an offender's nonoffense-related desert bases cause him to be punished. This kind of verdict would violate both the causation requirement and the justification standard. Yet the mechanisms described in each of these cases might improve accuracy at the case or systemic levels. If so, then all three of these cases would (on the views of both Cahill and Bierschbach and Stein) be unobjectionable.

\footnotetext{
${ }^{70}$ Bierschbach \& Stein, supra note 8, at 1206; see also Eric L. Muller, The Virtue of Mercy in Criminal Sentencing, 24 SETON HALl L. REV. 288, 299 (1993) (“[A] retributivist's primary concern is that a criminal sentence accurately reflect a criminal's just deserts.").

${ }^{71}$ Cahill, supra note 8, at 851.

${ }^{72} I d$. at 856 .
} 
Retributivist Criminal Procedure therefore departs from the goal of maximizing accuracy by ruling out mechanisms that would increase accuracy at the cost of generating invalid verdicts. Retributivist principles of criminal procedure cannot sacrifice the causation requirement or epistemic justification for other procedural goals. A society whose criminal procedure aims to maximize systemic accuracy should utilize the mechanism described in Proxy if doing so would lead to more accurate verdicts over the range of cases. Yet Refined Retributivism reaches the opposite conclusion: the proxy mechanism violates Retributivist Criminal Procedure because the defendant's offense-related desert bases do not exert the requisite causal influence.

To be sure, the proponent of Retributivist Criminal Procedure can see accuracy as an important procedural value. A Refined Retributivist might well construe verdict validity and accuracy as jointly paramount criminal procedure goals. ${ }^{73}$ Yet whether accuracy and validity are both overriding goals is a substantive question on which Refined Retributivists might disagree. The point here is not to resolve this question. Rather, for every version of Refined Retributivism, an invalid verdict provides sufficient grounds for condemning a punishment infliction as normatively unjustified.

To summarize: for an infliction of punishment to be normatively justified under Retributivist Criminal Procedure, (a) a defendant's offense-related desert bases must causally influence her liability to punishment, and (b) the adjudicator must at least be epistemically justified in believing (or have an epistemically justified belief) that the defendant has exhibited

\footnotetext{
${ }^{73}$ For example, some versions of Refined Retributivism might adopt a more demanding epistemic standard than justification (e.g., justified true belief or knowledge) as a precondition for normatively justifying any punishment infliction. To require that verdicts be true in addition to being justified is to enshrine accuracy as a goal of criminal procedure. On these more demanding epistemic standards, a verdict would be normatively justified only if it were both epistemically justified, causally appropriate, and accurate. See, e.g., LAUDAN, supra note 61, at 14. On this move, the epistemic goals of justification and causation would not have priority over the epistemic goal of accuracy. However, neither could justification (or causation) be traded off for accuracy. Rather, accuracy and validity would be jointly necessary for the normative justification of punishment inflictions.
} 
offense-related desert bases. If either the causation requirement or the justification standard is violated, then an infliction of punishment is normatively unjustified. At the system level, Retributivist Criminal Procedure calls for mechanisms that reduce or eliminate invalid verdicts, independently of whether such mechanisms realize other procedural values (such as fairness or accuracy).

\section{THE IMPLICATIONS OF RETRIBUTIVIST CRIMINAL PROCEDURE}

Retributivist Criminal Procedure seems to call for significant revision to U.S. criminal justice institutions. These revisionist tendencies provide a route to challenge both Retributivist Criminal Procedure and Refined Retributivism more broadly.

To be sure, Refined Retributivism and Retributivist Criminal Procedure can explain many features of due process. The notion that punishment must be meted out based on charged offenses is consistent with the causation requirement. So is the idea that the prosecution has the burden to prove each element of a charged offense. To adhere to the justification standard, each defendant must be allowed to contest her charges or conviction on the grounds of legal sufficiency — for example, by contending that the state has failed to produce sufficient evidence regarding each element of every crime for which the defendant is convicted.

However, Retributivist Criminal Procedure would seem to call for at least two broad types of changes to the U.S. criminal justice system. First, a direct application of Retributivist Criminal Procedure condemns a range of mechanisms that empower criminal justice officials to act pretextually, since pretextual actions are inconsistent with both the offense restriction and the causation requirement. Because such pretextual mechanisms are widely criticized, these revisionist implications might be applauded. Second, Retributivist Criminal Procedure condemns invalid verdicts. Yet many of procedural rules and norms that are central to the U.S. system of 
criminal justice (and to due process more broadly construed) have the effect of promoting invalid verdicts. Therefore, these procedural implications call into question whether Refined Retributivism can undergird a just or legitimate criminal justice system.

\section{A. Pretextual Mechanisms}

Directly applying Retributivist Criminal Procedure to criminal justice officials rules out pretextual actions. In general, a pretextual action is one where the official's action is prompted by considerations different than those that are sufficient to justify the action, and the prompting considerations are insufficient to justify the action. Pretextual actions violate the causation requirement and the offense restriction, generating cases in which the defendant's offense-related desert bases do not exert a robust causal influence on the official's action and, by implication, the defendant's punishment.

Pretextual mechanisms pervade every stage of the U.S. criminal justice system.

Pretextual investigative stops are exemplified by the facts of Whren v. United States. ${ }^{74}$ In 1993, a sport utility vehicle with two African-American occupants was stopped for an extended period at a traffic light in an area of Washington D.C. with high drug activity. Two undercover police officers noticed the SUV and made a U-turn toward it. The SUV reacted by speeding away and turning right without signaling. In violation of a departmental policy that prevented undercover officers from making traffic stops, the officers pulled over the SUV. Once pulled over, the officers saw several large plastic bags containing crack cocaine and arrested the driver. The officers' stop was likely pretextual. Although the officers had probable cause to pull the SUV over for the traffic offenses of speeding and turning without signaling, doing so was a violation of departmental policy. Assume arguendo that that the officers' intention was to investigate the

\footnotetext{
${ }^{74}$ Whren, 517 U.S. 816 (1996).
} 
crime of distributing narcotics (for which they lacked adequate justification to detain Whren) rather than the traffic offense (for which they had adequate justification). In Whren, the U.S. Supreme Court held that the evidence obtained in the traffic stop was properly introduced against Whren at trial. Because the officers had probable cause to believe that Whren had violated the traffic code, their stop of Whren's vehicle was reasonable under the Fourth Amendment to the U.S. Constitution.

The holding in Whren is inconsistent with Retributivist Criminal Procedure. Whren's non-offense-related desert bases (i.e., those related to his suspected drug dealing) prompted his detainment for the traffic violations. If Whren and his passenger had not been suspected drug dealers, then the undercover officers would not have stopped them for these minor traffic offenses. Pretextual actions like those in Whren allow for circumventions of the justification standard. The officers who arrested Whren did not have a legally sufficient reason to believe that he was a drug dealer. Retributivist Criminal Procedure holds, in general, that a lack of epistemic justification regarding an offender's desert bases is a barrier to normatively justifying his punishment. However, pretextual stops like those in Whren make the epistemic standard permeable: an officer can create the justification to search for drugs out of considerations that do not otherwise justify searching for drugs.

At the charging stage, pretextual prosecution involves "law enforcers [] go[ing] after a criminal defendant because they suspect him of one crime ... and then ... charg[ing] and convict[ing] him of a different crime, unrelated to and less severe than the first. ${ }^{, 75}$ The most famous case of pretextual prosecution is the U.S. federal government's pursuit and conviction of

\footnotetext{
${ }^{75}$ Daniel C. Richman \& William J. Stuntz, Al Capone's Revenge: An Essay on the Political Economy of Pretextual Prosecution, 105 Colum. L. ReV. 583, 584 (2005).
} 
Al Capone on criminal tax evasion charges, rather than for the vast array of more serious crimes that Capone committed as part of his criminal syndicate. Pretextual prosecution is the official policy of the United States Department of Justice and many state prosecutors' offices. ${ }^{76}$

Yet pretextual prosecution is inconsistent with Retributivist Criminal Procedure. Take Capone's case. Although Capone manifested desert bases related to the offense of tax evasion, these desert bases did not play the kind of direct or robust role in Capone's punishment that Refined Retributivism demands. Had another person failed to pay her taxes in the way that Capone did, she would almost certainly not have been prosecuted or punished as Capone was. Instead, pretextual prosecution allowed officials to punish Capone for being a gangster while avoiding establishing that Capone engaged in specific gangster activities. Punishing Capone because of these non-offense-related desert bases is inconsistent with Retributivist Criminal Procedure because it violates both the causation requirement and the offense restriction.

At the verdict stage, the vast majority of verdicts establishing criminal liability arise from plea bargaining, the process whereby a defendant agrees to plead guilty to an offense "in exchange for discretionary consideration on the part of the state," usually "some kind of assurance of a minimal sentence." 77 As the U.S. Supreme Court has observed, "criminal justice today is for the most part a system of pleas, not a system of trials." ${ }^{, 78}$ Most criminal cases in the

\footnotetext{
${ }^{76}$ As then-Attorney General John Ashcroft announced in the wake of the terrorist attacks on September 11, 2011, just as Robert F. Kennedy's Justice Department would 'arrest mobsters for 'spitting on the sidewalk' if it would help in the battle against organized crime," so too would Ashcroft's Justice Department "use the same aggressive arrest and detention tactics in the war on terror.” OFFICE OF INSPECTOR GENERAL, U.S. DEP'T OF JUSTICE,

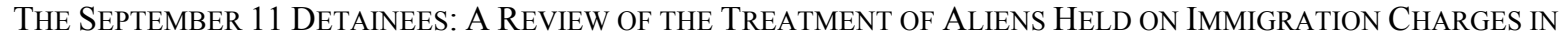
CONNECTION WITH THE INVESTIGATION OF THE SEPTEMBER 11 ATtACKS 12 (2003).

${ }^{77}$ Kenneth Kipnis, Criminal Justice and the Negotiated Plea, 86 ETHICs 93 (1976).

${ }^{78}$ Lafler v. Cooper, 132 S. Ct. 1376, 1388 (2012).
} 
United States are resolved through plea bargains, ${ }^{79}$ yet the process of plea bargaining is largely unregulated under the U.S. Constitution. ${ }^{80}$

Many commentators criticize plea bargaining on grounds of accuracy. The plea bargaining process is said to allow prosecutors to extract guilty pleas out of innocent defendants, ${ }^{81}$ as well as to allow those who committed an offense to be punished less than they deserve. ${ }^{82}$ Justice Scalia invoked both of these accuracy-based criticisms in noting that plea bargaining dynamics "effectively compel[] an innocent defendant to avoid massive risk by pleading guilty to a lesser offense; and for guilty defendants it often — perhaps usually—results in a sentence well below what the law prescribes for the actual crime." ${ }^{83}$ This inaccuracy is sometimes portrayed, not as a contingent characteristic of the U.S. system, but rather a function of the structural features that give rise to plea bargaining. ${ }^{84}$

Regardless of whether plea bargaining generates verdicts that do not correspond to an offender's desert bases, the Refined Retributivist should see it as problematic. Even where a plea generates an accurate punishment infliction, this infliction is almost certainly invalid. To

${ }^{79}$ In the United States, estimates are that more than $95 \%$ of criminal cases in both federal and state courts are resolved via plea bargain. Stephanos Bibas, Regulating the Plea-Bargaining Market: From Caveat Emptor to Consumer Protection, 99 CAL. L. REV. 1117, 1119 (2011).

${ }^{80}$ See, e.g., John H. Blume \& Rebecca K. Helm, The Unexonerated: Factually Innocent Defendants Who Plead Guilty, 100 CORNELl L. REV. 157, 166-67 (2014).

${ }^{81}$ See id., at 172-80; BRANDON L. GARRETT, CONVICTING THE INNOCENT: WHERE CRIMINAL ProseCUTIONS GO WRONG (2011).

${ }^{82}$ See Russell L. Christopher, The Prosecutor's Dilemma: Bargains and Punishments, 72 FORDHAM L. REV. 93 , 125-28 (2003) (contending that a prosecutor's offering a plea agreement for a sentence less than the defendant's culpability violates retributivism's categorical duty to punish culpable wrongdoing and wrongs the defendant by punishing him less than is deserved); MOORE, supra note 16, at 156.

${ }^{83}$ Lafler v. Cooper, 132 S. Ct. at 1397 (Scalia, dissenting).

${ }^{84}$ See William J. Stuntz, Plea Bargaining and Criminal Law's Disappearing Shadow, 117 HARV. L. REV. 2548, 2349-50 (2004). See also Christopher Slobogin, Plea Bargaining and the Substantive and Procedural Goals of Criminal Justice: From Retribution and Adversarialism to Preventive Justice and Hybrid-Inquisitorialism, 57 WILLIAM \& MARY L. REV. 1505, 1507 (2016); but see Cahill, supra note 8, at 855 (contending that retributivist should embrace consequentialist justification for plea bargaining based on systemic accuracy in distribution of deserved punishment). 
illustrate this point, consider an example based on Bordenkircher v. Hayes. ${ }^{85}$ Hayes was charged with the offense of forgery and, under a recidivist offender statute, faced life imprisonment if convicted. Hayes was offered the opportunity to plead guilty to forgery and be sentenced to five years' imprisonment. Hayes refused the deal, was convicted of forgery, and received a sentence of life imprisonment, which the Supreme Court upheld.

Imagine an alternative version of this scenario in which Hayes accepts the plea deal in order to avoid the possibility of being sentenced under the recidivist offender statute. Assume, arguendo, that Hayes actually committed the forgery and also that a prison term of five years is commensurate with Hayes's desert bases. In this alternative scenario, Hayes's bargaining position would exert a direct and robust causal influence on his punishment. If Hayes's desert bases had been the same but his bargaining position had been different (e.g., if he had information or testimony to provide to the state in exchange for a lesser sentence), then Hayes would have been offered a more favorable plea deal and punished less, if at all. Thus, even when a plea bargain is accurate, there is only a contingent connection between a defendant's offenserelated desert bases and the punishment that is inflicted. This contingency runs afoul of the causation requirement of Retributivist Criminal Procedure, which requires the connection to be more robust. Thus, punishment arising from a plea bargain is invalid and, in light of Refined Retributivism, normatively unjustified.

Thus, pretextual stops, pretextual prosecutions, and plea bargaining are all inconsistent with Retributivist Criminal Procedure. ${ }^{86}$ Whren was not punished for his offense-related desert

\footnotetext{
${ }^{85}$ Bordenkircher, 434 U.S. 357 (1978).

${ }^{86}$ To these charges of revisionism, the Refined Retributivist might offer a rebuttal based on the division of labor. On this rebuttal, Retributivist Criminal Procedure applies only to mechanisms that determine a defendant's liability to punishment, rather than to all mechanisms in the criminal justice system. The defendant's offense-related desert bases needn't cause the actions of police or the charging decisions of criminal justice officials. Any problems
} 
bases. Nor was Capone. Nor would Hayes have been, had he taken the plea deal. Since all of these features are common in the U.S. criminal justice system, Retributivist Criminal Procedure seems highly revisionist.

Whether these revisionist implications are objectionable depends on the legitimacy of pretextual mechanisms of criminal procedure. A Refined Retributivist might well embrace the charge of revisionism here. Each of the pretextual mechanisms described above is among the most highly criticized aspects of the criminal justice system. ${ }^{87}$ Critics have contended that these practices facilitate racial discrimination by officials ${ }^{88}$ and contribute to excessive and racially disparate punishment outcomes. ${ }^{89}$ Retributivist Criminal Procedure provides an independent criticism of each of these pretextual practices: namely, that they are inconsistent with the notion that an offender should be punished for an offense because she deserves to be punished for that offense.

\section{B. Causation-Obscuring and Justification-Obscuring Mechanisms}

Some rules of criminal procedure obscure information relevant to the causation requirement and/or the justification standard, thereby increasing the likelihood of invalid verdicts. These mechanisms are difficult to reconcile with Retributivist Criminal Procedure. Yet many of these

introduced at investigative or charging stages can be resolved if the offender's desert bases exert a direct and robust causal influence on the verdict itself. This division-of-labor rebuttal seems powerful, although fully evaluating it is outside the scope of this paper. However, two points about the division-of-labor rebuttal are worth noting. First, the rebuttal concedes that retributivism cannot be the sole principle for regulating the criminal justice system, a concession that some retributivists would be unwilling to make. Second, even if the rebuttal succeeds, Retributivist Criminal Procedure would still have revisionist implications regarding plea bargining, since this practice determines liability to punishment. Thanks to Mihailis Diamantis for encouraging discussion of this rebuttal.

${ }^{87}$ See, e.g., Paul Butler, The White Fourth Amendment, 43 TEX. TECH L. REV. 245, 250 (2010); William Stuntz, The Collaps of American Criminal Justice 295, 301 (2011).

${ }^{88}$ See, e.g., Kevin R. Johnson, How Racial Profiling in America Became the Law of the Land: United States v. Brignoni-Ponce and Whren v. United States and the Need for Truly Rebellious Lawyering, 98 GEO. L.J. 1005, 1075 (2010).

${ }^{89}$ See, e.g., John F. Pfaff, The Micro and Macro Causes of Prison Growth, 28 GA. ST. U. L. REV. 1239, 1241 (2012). 
mechanisms are core features of an adversarial system of criminal justice, and some are basic matters of due process.

The rules and norms regarding legal representation of criminal defendants work to frustrate both the causation requirement and the justification standard. The Sixth Amendment of the U.S. Constitution guarantees the assistance of counsel in criminal proceedings, a provision that has been interpreted to require states to provide counsel for indigent defendants charged with felonies. ${ }^{90}$ Beyond these formal requirements, widely recognized professional norms among U.S. criminal defense lawyers enshrine an ideal of "zealous advocacy." "Implicit in the notion of zealous advocacy is that defense counsel is authorized and should be committed to use aggressive tactics (such as strategic delay, presenting misleading testimony, arguing to the jury that evidence supports factual inferences that the lawyer knows to be untrue, calling for nullification, or disclosing information that a lawyer knows "does not contribute to informed determination on the merits because such disclosure injures the prosecution or witnesses”) whenever doing so is "advantageous to the client.",92

The norms of zealous advocacy are hypothesized to increase the likelihood of invalid verdicts, both systematically and at the case level. As William Simon notes, such norms not only

${ }^{90}$ Gideon v. Wainwright, 372 U.S. 335 (1963).

${ }^{91}$ See, e.g., W. William Hodes, Lord Brougham, the Dream Team, and Jury Nullification of the Third Kind, 67 U. COLO. L. REV. 1075, 1083 (1996) ("According to the professional conduct rules applicable to American lawyers, once defense counsel enter a case, they must represent their clients 'zealously, within the bounds of law.' This means that defense counsel must attempt to secure the acquittal of the accused, whether or not he is factually guilty, and even if the lawyers know that he is. It is not the obligation of defense counsel to seek the truth-indeed ... exactly the opposite is required when the defendant is known by his lawyers to be factually guilty! Furthermore, almost everyone agrees that such situations - where zealous representation is synonymous with obfuscating and distorting the truth - are common.") (citations omitted).

${ }^{92}$ William H. Simon, The Ethics of Criminal Defense, 91 MiCH. L. REV. 1703 (1993). Although defendants in the United States have a constitutional right to effective assistance by legal counsel, they do not also have the right that counsel use the aforementioned tactics of aggressive defense. See Margareth Etienne, Remorse, Responsibility, and Regulating Advocacy: Making Defendants Pay for the Sins of Their Lawyers, 78 NYU L. REV. 2103,2117 (2003). Rather, the point is that aggressive defense tactics and norms of zealous defense are thought to be part of contemporary U.S. criminal justice system, and neither is consistent with Retributivist Criminal Procedure. 
"treat[] all defendants alike" in trying to "help [them] thwart conviction regardless of whether or not they are guilty," but also "help many defendants present themselves as something other than they are" by "portray[ing] defendants who have committed acts with which they have been charged as not having committed them" and "orchestrat[ing] clients' behavior in court ... to conform to the judge's and jury's stereotypes about how a respectable, law-abiding citizen looks and behaves. ${ }^{.93}$ Many aggressive tactics aim to focus the adjudicator's attention on considerations unrelated to the defendant's offense-related desert bases, such as the possible culpability of a third party ${ }^{94}$ or the race of the defendant, the victim, or the police. ${ }^{95}$

An example of this last phenomenon is Johnny Cochran's defense of O.J. Simpson against charges that he murdered Nicole Brown Simpson and Ronald Goldman. In closing arguments, Cochran urged jurors to acquit Simpson and therefore "send a message" that the Los Angeles Police Department's deception and racism should not be tolerated. ${ }^{96}$ Cochran's tactic was intended to shift the jury's attention away from the question of whether there was good reason to believe that Simpson committed the murders and toward the question of whether there was good reason to believe that Los Angeles police were racially biased. To the extent that this

\footnotetext{
${ }^{93}$ Simon, supra note 92, at 1713. Although Simon does not advocate this position, several other legal ethicists do. See generally Monroe Freedman, Professional Responsibility of the Criminal Defense Lawyer: The Three Hardest Questions, 64 Mich. L. REV. 1469 (1966); Abbe Smith, Defending Defending: The Case for Unmitigated Zeal on Behalf of People Who Do Terrible Things, 28 HoFSTRA L. ReV. 925 (1999).

${ }^{94}$ David Luban, Rediscovering Fuller's Legal Ethics, 11 GEO. J. Legal ETHICS 801, 829 (1998) (“[C]asting suspicion on innocent persons is one of the most common techniques of the [criminal] defender, and every defender that I know would regard failing to use the technique as close to malpractice.").

${ }^{95}$ See, e.g., Smith, supra note 93, at 954; Eva S. Nilsen, The Criminal Defense Lawyer's Reliance on Bias and Prejudice, 8 Geo. J. Legal ETHics 1, 9 (1994).

${ }^{96}$ David B. Wilkins, Straightjacketing Professionalism: A Comment on Russell, 95 Mich. L. Rev. 795, 815-19 (1997); Hodes, supra note 91, at 1080-81 (“'T] The Simpson lawyers cannot be faulted or branded as 'unethical' for making jury nullification ... the centerpiece of their defense. Indeed, given the duty of zealous advocacy, it was obligatory for these ethical lawyers to make the attempt, one they concluded that doing so was tactically sound.") (citations omitted).
} 
tactic was successful, the jury's acquittal of Simpson did not reflect a collective judgment about whether he manifested offense-related desert bases.

The Simpson example indicates how zealous advocacy might undermine the causation requirement. If the defense attorney successfully shifts the question, then the defendant's desert bases (or lack thereof) do not exert the type of robust causal influence on his liability to punishment that Retributivist Criminal Procedure calls for. In other words, the causation requirement is open to violation whenever the subject is switched from a question about the defendant's desert bases to some other question, regardless of how the jury resolves that other question. Further, aggressive defense techniques like Cochran's, if successful, are inconsistent with the justification standard. False acquittals (or acquittals in cases where there is sufficiently good reason to believe that the defendant has committed an offense) are epistemically unjustified in the same way that false convictions are. ${ }^{97}$ Retributivist Criminal Procedure, then, is in tension with the norm of zealous advocacy among criminal defense attorneys.

Rules excluding evidence from use by the prosecution also promote invalid verdicts, and so may also be condemned by Retributivist Criminal Procedure. Some such evidentiary rules preclude introducing entire categories of evidence as part of the prosecution's case-in-chief. ${ }^{98}$ Jeremy Bentham offered an accuracy-based argument for the abolition of these evidentiary

\footnotetext{
${ }^{97}$ David Luban notes that "aggressive defense" describes only a "small fraction of criminal representations involving wealthy clients and top-shelf defenders" because "[ $\mathrm{t}]$ he typical client is poor, and the typical defender is not paid enough to engage in individualized advocacy, let alone [aggressive defense]." Luban, supra note 94, at 1763-64. The situation that Luban describes is actually desirable under Retributivist Criminal Procedure: to the extent that aggressive defense promotes verdict invalidity, the less of it that a system realizes, the better.

${ }^{98}$ Examples in the United States include rules regulating the use of hearsay evidence (FED. R. EVID. 802), evidence of prior bad acts (under FED. R. EVID. 404(a)), and character evidence (under FED. R. EVID. 404(b) and 413-15).
} 
rules. ${ }^{99}$ In the words of one commentator, Bentham saw "fixing rules for the exclusion of evidence [as] more likely to cause misdecision on deceptive evidence." ${ }^{\prime 100}$ Bentham's argument against such evidentiary rules is therefore "a straightforward application of his general utilitarian theory of procedure to the special case of evidence."101

Unlike Bentham's view, Retributivist Criminal Procedure favors certain exclusionary rules, particularly rules prohibiting introduction of evidence regarding the defendant's character or prior bad acts as part of the prosecution's case-in-chief. To be sure, it is an open question whether introducing such evidence increases the overall accuracy of verdicts. ${ }^{102}$ Yet regardless of how such evidence bears on the accuracy of verdicts, it compromises their validity whenever a defendant is deemed liable to punishment based on considerations other than his offense-related desert bases. The logic of this position is captured by the U.S. Supreme Court's opinion in Michelson v. United States:

The state may not show defendant's prior trouble with the law, specific criminal acts, or ill name among his neighbors, even though such facts might logically be persuasive that he is by propensity a logical perpetrator of the crime. The inquiry is not rejected because character is irrelevant; on the contrary, it is said to weigh too much with the jury and to so overpersuade them as to prejudge one with a bad

${ }^{99}$ See Jeremy Bentham, Rationale of Judicial Evidence, in 7 THE WORKS OF JEREMY BENTHAM 338 (John Bowring ed., 1843).

${ }^{100}$ Gerald J. Postema, Bentham AND the Common LaW Tradition 348 (1986).

${ }^{101} I d$.

${ }^{102}$ Compare Larry Laudan \& Ronald J. Allen, The Devastating Impact of Prior Crimes Evidence and Other Myths of the Criminal Justice Process, 101 J. CRIM. LAW \& CRIMINOLOGY 493, 522 (2011) ("If, as appellate courts are constantly claiming, the aim of a trial is to get at the truth, then a system in which jurors factor prior convictions - either known or presumed - into their calculations of guilt and innocence is probably more truthconducive than a system in which priors were ignored or treated as irrelevant.") with David P. Leonard, In Defense of the Character Evidence Prohibition: Foundations of the Rule Against Trial by Character, 73 IND. L.J. 1161, 1187-88 (1998) ("The character rule is undeniably designed in part for adjudicatory purposes. By targeting the unfairly prejudicial effect of bad character evidence, the rule seeks to prevent inaccurate verdicts caused by overvaluation of the evidence...."). 
general record and deny him a fair opportunity to defend against a particular charge. ${ }^{103}$

Retributivist Criminal Procedure provides an argument in favor of rules excluding evidence of bad character and prior bad acts. Such rules serve to safeguard violations of the offense restriction and the causation requirement.

However, Refined Retributivism shares Bentham's skepticism about evidentiary rules that tend to promote invalid verdicts. One example from the United States is the Exclusionary Rule, which precludes the prosecution from introducing evidence obtained by the state in violation of a defendant's constitutional rights - for example, as the result of a search or seizure that violates the Fourth Amendment or arising from an interrogation that violates the Fifth Amendment - as part of its case-in-chief. ${ }^{104}$ As a doctrinal matter, the Exclusionary Rule is justified solely on grounds of deterring police misconduct. ${ }^{105}$ Therefore, the ostensible logic of the Exclusionary Rule is inconsistent with Retributivist Criminal Procedure's attribution of preeminent importance to verdict validity. At least as articulated by the U.S. Supreme Court, the Exclusionary Rule presupposes what Retributivist Criminal Procedure denies: that both the causation requirement and the justification standard can be sacrificed for other procedural goals.

Apart from this doctrinal inconsistency, there is a deeper tension between the Exclusionary Rule and Retributivist Criminal Procedure. The Exclusionary Rule restricts the factfinder's access to information that is relevant to determining whether the defendant

${ }^{103}$ Michelson, 335 U.S. 469, 475-76 (1948).

${ }^{104}$ See Mapp v. Ohio, 367 U.S. 643 (1961). The use of the term "Exclusionary Rule" is meant to distinguish this mechanism from the other mechanisms for precluding factfinders from considering categories of evidence.

${ }^{105}$ Under the Supreme Court's current doctrine, the main function of the Exclusionary Rule is to deter police misconduct. United States v. Janis, 428 U.S. 433, 446 (1976). In prior decisions, the Court has also justified the rule as a way of preserving the integrity of the judicial process. Mapp v. Ohio, 367 U.S. at 659 (quoting Elkins v. United States, 364 U.S. 206, 222 (1960)). Both the deterrence and the judicial integrity rationales are inconsistent with Retributivist Criminal Procedure. 
manifested offense-related desert bases, therefore increasing the chance of an invalid verdict in any particular case and the number of invalid verdicts overall. To illustrate this point, consider an alternative version of the Whren case in which the trial court excluded evidence obtained from Whren's vehicle on the grounds that the seizure and search violated the Fourth Amendment. In this scenario, the jury would not have been allowed to consider evidence directly relevant to whether Whren manifested desert bases related to the drug offenses with which Whren was charged. In the absence of such evidence, the jury could either acquit or convict Whren of the charges. In this alternative scenario, an acquittal of Whren would have been invalid, ${ }^{106}$ since there was sufficiently good evidence that he manifested offense-related desert bases and therefore (according to Refined Retributivism) that he deserved to be punished for the offense. On the other hand, if Whren had been convicted in the absence of this search-related evidence, then the conviction might also have been invalid — for example, if the jury had made inferential moves to fill in gaps created by the exclusion of directly relevant evidence. ${ }^{107}$

${ }^{106}$ This conclusion presupposes a standard that construes validity in terms of the objective or internal reasons in favor of a verdict, rather than the reasons available to the adjudicator at the time of rendering the verdict.

${ }^{107}$ Laudan and Allen describe this sort of inferential move regarding evidence of prior crimes. See Laudan and Allen, supra note 102, at 508-9. Under the Federal Rules of Evidence in the United States, the prosecution cannot introduce evidence of a defendant's prior crimes in order to prove bad character or propensity. However, defendants can introduce evidence of good character or a clean record, and the prosecution can introduce evidence of a defendant's bad character or prior bad acts for collateral purposes like impeachment of the defendant's testimony. According to Laudan and Allen, this setup creates a gap: if the defendant has no prior convictions, then the "jury is apt to be told that [by the defendant] in no uncertain terms." Yet "[e]ven when the judge has excluded a defendant's priors, the [defendant] must adopt a very different profile during trial than a defendant without priors would, a profile that should leave few jurors in doubt that [the defendant] has prior convictions, even if the latter go unmentioned explicitly in the trial." Id. at 508. According to Laudan and Allen, the results of both empirical and experimental studies suggest that juries routinely make this kind of inferential move. Id. at 509.

A similar gap applies to evidence that arises from an unlawful search or seizure. Here, too, the prosecution is precluded from introducing unlawfully obtained evidence as part of its case-in-chief, although it can introduce such evidence for collateral purposes like impeaching the defendant's testimony. See Walder v. United States, 347 U.S. 62 (1954). Furthermore, if there is no incriminating evidence, then the defendant can highlight this fact. Consider how Laudan and Allen's logic might apply to Whren's case if Whren had succeeded in excluding the evidence of his possession on the grounds that police officers acted unlawfully in stopping him. The prosecution would not have been able to introduce direct evidence of Whren's possession as part of its case-in-chief. However, Whren would likely have been precluded from testifying on his own behalf. Had Whren testified to the effect that he did not 
Retributivist Criminal Procedure is therefore in tension with norms of zealous advocacy and the Exclusionary Rule. Given these implications, Refined Retributivists are (perhaps surprisingly) allied with consequentialists like Bentham on many questions of criminal procedure. ${ }^{108}$ Whereas consequentialists would justify these revisions to the extent that they increase verdict accuracy, Retributivist Criminal Procedure might justify them as a way to avoid invalid verdicts. ${ }^{109}$

Norms of zealous advocacy and the Exclusionary Rule are not necessarily central to due process. As a doctrinal matter, neither of these mechanisms are considered "fundamental to the American scheme of justice," which is one standard for characterizing requirements of due process. ${ }^{110}$ A defendant whose lawyer provides less-than-zealous advocacy is not entitled to a

possess drugs, the state could have used the fruits of the unlawful stop to impeach his testimony. Thus, on Laudan and Allen's logic, from the absence of Whren's testifying that he did not possess the drugs, the jury might infer that he did possess the drugs.

Inferential moves like the ones that Laudan and Allen describe are violations of Retributivist Criminal Procedure because the defendant's offense-related desert bases do not play the kind of direct, robust causal role in the judgment that the defendant is liable to punishment that Refined Retributivism requires. To the extent that the defendant's offense related desert bases play some causal role in this judgment, it would seem to be an instance of an indirect or "deviant" kind of causation. See Sorensen, supra note 49, at 172. Punishment in such cases would violate both the directness and robustness aspects of the causation requirement, for the same reasons that the mechanism described in the Lottery case does.

${ }^{108}$ To be sure, this overlap would not be surprising to commentators who see accuracy as the overriding procedural goal of both retributivists and consequentialists. See, e.g., Bierschbach and Stein, supra note 8; Cahill, supra note 8. Nor would the overlap be surprising to a punishment theorist (such as Laudan) who takes verdict validity and accuracy as equally important criminal procedure goals.

${ }^{109}$ For example, Bentham decried aggressive defense techniques by criminal defense attorneys, on the grounds that using these techniques was functionally equivalent to complicity in a client's crime. BENTHAM, supra note 99, at 474-75. The consequentialist would likely agree with Judge J. Harvie Wilkinson's observation that the Exclusionary Rule's operation in the U.S. criminal justice system allows for criminal trials to be "sever[ed] ... from external reality to an unacceptable extent. Exclusions hide truth, rather than seeking to reveal it. That is not a comfortable place for a trial, or any honest instrument of inquiry, to be." J. Harvie Wilkinson III, In Defense of American Criminal Justice, 67 VAND. L. REV. 1099, 1164 (2014).

${ }^{110}$ Duncan v. Louisiana, 391 U.S. 145 (1968). 
reversal of her conviction. ${ }^{111}$ Moreover, states are not required to adopt the Exclusionary Rule for violations of state constitutional provisions. ${ }^{112}$ Further, both zealous advocacy and the Exclusionary Rule are routinely criticized by commentators, in part for their tendency to produce inaccurate verdicts. $^{113}$

However, the logic of Retributivist Criminal Procedure is in tension with a number of other procedural rules that are more fundamental to due process. Among these are the defendant's rights to confront adverse witnesses, ${ }^{114}$ to have the prosecution disclose evidence that tends to prove the defendant's innocence or provides a basis for impeaching government witnesses, ${ }^{115}$ against being compelled to provide incriminating evidence against himself, ${ }^{116}$ against double jeopardy, ${ }^{117}$ and against having coerced confessions introduced against him. ${ }^{118}$ Likewise, a defendant's rights to be tried by a jury reflecting a "fair cross-section" of the

${ }^{111}$ Strickland v. Washington, 466 U.S. 668, 690 (1984) (6th Amendment standard for competence by appointed attorney is whether specific acts or omissions by the attorney were "outside the wide range of professionally competent assistance," thus precluding he "adversarial testing process" from "work[ing] in the particular case.").

112 See, e.g., Virginia v. Moore, 553 U.S. 164, 178 (2008) (exclusion of evidence from arrest that violated "state law alone" not required, since "it is not the province of the Fourth Amendment to enforce state law").

${ }^{113}$ See, e.g., Christopher Slobogin, Why Liberals Should Chuck the Exclusionary Rule, 1999 U. ILL. L. REV. 363 (1999); Akhil Reed Amar, Fourth Amendment First Principles, 107 HARV. L. REV. 757 (1994). Recent defenses of the Exclusionary Rule as a requirement of due process (see, e.g., Richard M. Re, The Due Process Exclusionary Rule, 127 HARV. L. REV. 1885 (2014)) and political morality (see, e.g., H. L. Ho, The Criminal Trial, the Rule of Law and the Exclusion of Unlawfully Obtained Evidence, 10 CRIM. LAW \& PHIL. 109 (2016)) do not render it compatible with Retributivist Criminal Procedure, since these arguments do not establish that the Exclusionary Rule meets the goal of reducing and/or eliminating invalid verdicts.

${ }^{114}$ U.S. Const., Amend. VI ("In all criminal prosecutions, the accused shall enjoy the right ... to be confronted with the witnesses against him.”); Crawford v. Washington, 541 U.S. 36 (2004).

115 Brady v. Maryland, 373 U.S. 83 (1963).

${ }^{116}$ U.S. Const., Amend. V (“[N]o person ... shall be compelled in any criminal case to be a witness against himself.").

${ }^{117}$ U.S. Const., Amend. V ("[N] or shall any person be subject for the same offence to be twice put in jeopardy of life or limb.").

${ }^{118}$ Dickerson v. United States, 530 U.S. 428, 433-35 (2000). 
community, ${ }^{119}$ against racial discrimination by state officials in the composition of a jury, ${ }^{120}$ and even to a jury trial itself ${ }^{121}$ are difficult to square with Retributivist Criminal Procedure. As a doctrinal matter, the rationale for each of these rules under U.S. law is based on considerations other than the promotion of accurate and/or justified verdicts. ${ }^{122}$ Indeed, many of these rules are justified regardless of whether they tend to make verdicts less accurate or less justified. ${ }^{123}$

Moreover, each of these rules significantly increases (at both the case and system levels) the prospect of invalid verdicts. For example, consider the Fifth Amendment's privilege against self-incrimination, which prohibits the state from forcing the defendant to testify under a wide variety of circumstances. Retributivist Criminal Procedure would seem to condemn the privilege, regardless of whether abolishing the privilege affects the accuracy of verdicts. The privilege obscures the causation requirement to the extent that the defendant's testimonial evidence

${ }^{119}$ Taylor v. Louisiana, 419 U.S. 522 (1975).

${ }^{120}$ Batson v. Kentucky, 476 U.S. 79 (1986).

${ }^{121}$ U.S. Const., Amend. VI ("In all criminal prosecutions, the accused shall enjoy the right to a speedy and public trial, by an impartial jury of the state and district wherein the crime shall have been committed....")

${ }^{122}$ Some of these mechanisms are justified on grounds of fairness to the defendant. See, e.g., Brady v. Maryland, 373 U.S. 83, 87 (1963) (noting that exclusion of evidence is justified based on "avoidance of an unfair trial to the accused"); Murphy v. Waterfront Commission of New York Harbor, 378 U.S. 52, 55 (1964) (privilege against self-incrimination "reflects many of our fundamental values and most noble aspirations," like the "unwillingness to subject those suspected of crime to the cruel trilemma of self-accusation, perjury or contempt"). Some of these mechanisms are justified in terms of political legitimacy. See, e.g., Taylor v. Louisiana, 419 U.S. 522 , 526 (1975) (purpose of the fair cross-sectional requirement is to guard against the exercise of arbitrary power, or to "make available the common sense judgment of the community as a hedge against the overzealous or mistaken prosecutor and in preference to the professional, or perhaps overconditioned or biased response of a judge"); United States v. Scott, 437 U.S. 82, 99 (1978) (Double Jeopardy clause "guards against Government oppression"); Apprendi v. New Jersey, 530 U.S. 466, 477 (2000) (trial by jury is a "bulwark" against "oppression and tyranny on the part of rulers"). Others are justified based on broader constitutional values, such as the importance of preventing state officials from engaging in racial discrimination. Batson v. Kentucky, 476 U.S. 79, 86-87 (1986) (racial discrimination by prosecutors in jury composition violates the equal protection rights of jurors, as well as "undermin[ing] public confidence in the fairness of our system of justice.").

${ }^{123}$ See, e.g., Crawford v. Washington, 541 U.S. 36, at 62 ("Dispensing with confrontation because testimony is obviously reliable is akin to dispensing with jury trial because a defendant is obviously guilty."); Lisenba v. California, 314 U.S. 219, 326 (1941) (purpose of rule requiring confessions to be voluntary in order to be admitted "is not to exclude presumptively false evidence, but to prevent the fundamental unfairness in the use of evidence, whether true or false"). 
provides direct evidence about whether she manifested offense-related desert bases. Excluding this type of evidence increases the possibility that the defendant's offense-related desert bases will not causally influence the verdict. It also increases the chances that a defendant's nonoffense-related desert bases will exert influence. Both of these prospects are unacceptable under Retributivist Criminal Procedure, since each increases the likelihood of invalid verdicts.

Likewise, the privilege obscures epistemic justification by precluding the factfinder from accessing a source of potentially good reasons. In light of these effects, it seems plausible that, ceteris peribus, a system in which defendants lacked rights against self-incrimination would have fewer invalid verdicts than a system in which they had this right. ${ }^{124}$

The same logic applies to all of the other procedural rules described above. These rules are justified by goals (such as fairness or legitimacy or accuracy) that are hostile to Retributivist Criminal Procedure. The effect (and, in many cases, the point) of these rules is to preclude an offender's desert bases from causing his liability or to frustrate the realization of the justification standard. Therefore, each of these procedural mechanisms are difficult to reconcile with Retributivist Criminal Procedure. .

These tensions should trouble the Refined Retributivist. A comprehensive account of due process in criminal procedure would be necessary to fully vindicate the importance of each of these rules. Absent such an account, it is enough to note that each of these features meets the lower due process standard of being "fundamental to the American scheme of justice,"125 and many of these features meet the higher due process standard of being part of the "very essence of

\footnotetext{
${ }^{124}$ Retributivist Criminal Procedure therefore supports abolishing the privilege on grounds that resemble those advanced by Bentham and others - namely, that the privilege affects the accuracy of verdicts by benefitting the guilty and not the innocent. See Jeremy Bentham, A Treatise On Judicial Evidence (1825), at 241; Bentham, supra note 99, at 451-4.

${ }^{125}$ Duncan v. Louisiana, 391 U.S. 145 (1968).
} 
a scheme of ordered liberty." ${ }^{, 26}$ At first glance, Retributivist Criminal Procedure not only fails to capture why these procedural rules are important, but also can be read to imply that the criminal justice system should modify or eliminate them. ${ }^{127}$

\section{CONCLUSION}

Retributivist theories of punishment can be described in both simple and refined versions, depending on how an offender's desert bases must figure in the effectuation of normatively justified punishment. Refined Retributivism seems, at first blush, to be superior to Simple Retributivism. Simple Retributivism allows for a range of unjust and illegitimate mechanisms of criminal procedure that Refined Retributivism rules out. Yet, Refined Retributivism (via Retributivist Criminal Procedure) also condemns significant portions of the U.S. criminal justice system. These procedural implications lead to the conclusion that Refined Retributivism, like Simple Retributivism, should not undergird a criminal justice system.

Retributivists have several possible responses to the indictment presented here. Perhaps, contrary to the arguments raised in Part I, Simple Retributivism can be formulated in a manner consistent with due process after all. Perhaps an alternative version of Retributivist Criminal Procedure (say, one that does not prioritize verdict validity) is better supported than the one contemplated here. Perhaps, contrary to the understanding of due process utilized in Part III, the mechanisms in tension with Retributivist Criminal Procedure are not actually fundamental to the

${ }^{126}$ Palko v. Connecticut, 302 U.S. 319, 325 (1937).

${ }^{127}$ Consider the following position, which is consistent with Refined Retributivism. The goal of retributivist criminal procedure is not to ensure valid verdicts, but rather to protect against invalid inflictions of punishment. Therefore, every normatively infliction of punishment must satisfy the causation requirement and justification standard. However, invalid acquittals are not necessarily problematic. Procedural values unrelated to an offender's desert bases might both prompt and normatively justify acquitting her, even if these same considerations could not (consistent with Refined Retributivism) prompt and normatively punishing her.

As far as I know, no retributivist has articulated anything like this position. Moreover, defending this position would be a tall order. However, such a position might tame some (although not all) of the revisionist tendencies of Retributivist Criminal Procedure. Thanks to Nathan Hanna for suggesting this point. 
U.S. scheme of criminal justice or to due process per se. Perhaps retribution should only serve as an abstract ideal, rather than as the general aim of the criminal justice system. Yet if the procedural implications of retributivism identified here are sound, then the retributivist faces a choice. She can advocate for retributivism or she can advocate for due process, but she cannot consistently advocate for both.

The failure to address the theoretical importance of criminal procedure is not unique to retributivists. Indeed, non-retributivist theories face many of the same obstacles in reconciling normatively justified punishment with due process. Those who disagree with the preceding analysis of retributivism and criminal procedure might still accept that the question "What is the point of criminal punishment?" is closely connected to the question "What is the point of criminal procedure?" The former question is asked and answered often, and in a variety of ways. The latter question deserves closer attention in its own right, not just because of its bearing on the former. 